Deliberationes tudományos folyóirat

14. évfolyam 1. szám 2021/1, 25-34.

Kézirat beérkezése: 2021.05.07.

Kézirat befogadása: 2021.08.16.

DOI: 10.54230/Delib.2021.1.25
Deliberationes Scientific Journal

Vol.14; Ed.No. 1/2021, pages:.25-34

Paper submitted: 7th May 2021

Paper accepted: 16th August 2021

DOI: $10.54230 /$ Delib.2021.1.25

\title{
A PASZTORÁLIS TANÁCSOK ILLETÉKESSÉGE A LELKIPÁSZTORI MUNKÁT ÉRTINTŐ KÉRDÉSEKBEN
}

Linczenbold Levente

Egri Hittudományi Főiskola

\begin{abstract}
Absztrakt
A II. vatikáni zsinat és azt követő dokumentumok - a lelkipásztori kihívásokra való tekintettel -, nagyon ajánlják a pasztorális tanács létrehozását az egyházmegyékben, világiakat is bevonva abba. A tanács feladata, hogy fölvesse és megtárgyalja a lelkipásztori munkát érintő kérdéseket és gyakorlati következtetésekre jusson.

Plébániai szinten is nagy igény jelentkezett a pasztorális tanács létrehozására, amelynek feladata és illetékessége hasonló az egyházmegyei pasztorális tanácséhoz. A jelenlegi tanítóhivatali megnyilatkozások is sürgetik a plébániai közösségek megtérését, amelyben jelentős szerepe van a pasztorális tanácsnak.

Az egyházmegyei és plébániai pasztorális tanácsadó szervek vizsgálata felveti azt a kérdést, hogy vajon a pasztorális tanács jogi struktúrája e két szinten csupán analogikus, vagy mélyebb teológiai összefüggést mutat. Ezeknek a tanácsoknak van-e a zsinat által megfogalmazott teológiai alapjuk? A hívők egyetemes papságából fakadó sajátos küldetésük milyen hatással van a képviseleti jelleg kidomborítására, és ez kellően kifejeződik-e a tanácsokra vonatkozó jogszabályi környezetben? A püspök és az ő megbízott klerikusa, valamint a tanács tagjai közötti viszony kérdését, a hatalom centralizálása vagy decentralizálásának alapján kell-e vizsgálnunk, vagy inkább a communio teológiai struktúrájának valóságából kell-e kiindulnunk?

A pasztorális tanácsok teológiai és jogi megalapozásának vizsgálata választ ad a fentebb megfogalmazott kérdésekre, valamint a nemzetközi jogban is különlegességnek számító magyar sajátosság is bemutatásra kerül, miszerint az Egyházközségek Képviselő Testülete látja el a plébániai pasztorális tanács feladatát.
\end{abstract}

Kulcsszavak: pasztorális tanács, lelkipásztori munka, pasztorális terv, reprezentativitás, tanácsadási jogkör 


\title{
COMPETENCE OF PASTORAL COUNCILS IN MATTERS PERTAINING TO PASTORAL WORK
}

\author{
Levente Linczenbold \\ Thelogical College of Eger
}

\begin{abstract}
The Second Vatican Council and subsequent documents, in view of the pastoral challenges, strongly recommend the establishment of a pastoral council in the dioceses, in which mainly the laity should be involved. The role of the council is to raise and discuss issues related to pastoral work and to reach practical conclusions.

There was also a great need at the parish level for the establishment of a pastoral council, the task and competence of which were similar to that of the diocesan pastoral council. Current magisterial declarations also urge the conversion of parish communities, in which the pastoral council has a significant role to play.

An examination of the diocesan and parish pastoral advisory bodies raises the question of whether the legal structure of the pastoral council at these two levels shows only an analogous or rather deeper theological connection. Do these councils have a theological basis formulated by the Council? What impact does the particular mission of the faithful arising from the universal priesthood have on emphasizing representation, and is this sufficiently reflected in the legislation pertaining these councils? Should the question of the relationship between the bishop and his commissioned cleric and the members of the council be examined on the basis of the centralization or decentralization of power, or should we rather start from the reality of the theological structure of communio?

The examination of the theological and legal basis of pastoral councils provides answers to the questions formulated above, as well as to present the Hungarian peculiarity which is also a special feature in international law, that is, the Parish Board of Representatives which performs the task of the parish pastoral council.
\end{abstract}

Keywords: pastoral council, pastoral work, pastoral plan, representation, consultative vote 
Az egyház - mint Isten népe a Szentlélek irányítása alatt - már a kezdetektől fogva, folytonosan keresi a megfelelő válaszokat a világ kihívásaira, $s$ ezt a célt szolgálja a lelkipásztori terv készítése is. A tervezés, előrelátás, a problémák megoldásának igénye végigvonul az egyház egész történelmén. Az egyházi vezetők mindig is keresték azt a megoldást, hogy mi módon feleljenek meg a lehető legjobban a hívek pasztorális igényeinek. A pasztorális kihívásokkal való szembenézésre, azok megoldásához szükség van az egész egyházmegyét, valamint a plébániát átfogó pasztorális tervre.

A II. vatikáni zsinat dokumentumai, valamint az azt követő időszakban megjelent egyházi dokumentumok is „nagyon ajánlják” a pasztorális tanács létrehozását. Annak feladata egy szisztematikus lelkipásztori terv elkészítése, mérlegelve az egyházmegyében müködő lelkipásztori tevékenységet.

Az egyházmegyei és plébániai pasztorális tanács mint a püspök, valamint a papok és a világiak együttműködését szolgáló testületének vizsgálata felveti azt a kérdést, hogy a pasztorális tanács jogi struktúrája e két szinten csupán analogikus, vagy mélyebb teológiai összefüggést mutat? Ezeknek a tanácsoknak van-e a zsinat által megfogalmazott teológiai alapjuk? A püspök és az ő megbízott klerikusa, valamint a tanács tagjai közötti viszony kérdését, a hatalom centralizálása vagy decentralizálásának alapján kell vizsgálnunk, vagy inkább a communio teológiai struktúrájának valóságából kell kiindulnunk?

\section{AZ EGYHÁZMEgYei PASZTORÁlis TANÁCS TEOLÓgIAI JELENTŐSÉGÉRöL}

A pasztorális vagy lelkipásztori tanács fogalma újdonság a hatályos Kódexben, ennek forrásai a II. vatikáni zsinat dokumentumában lelhetők fel (Denis, 1967).

A Christus Dominus határozat 27. pontja szerint „nagyon kívánatos”, hogy minden egyházmegyében létesüljön külön lelkipásztori tanács; feladatának pedig azt jelöli meg, hogy „felvesse és megtárgyalja a lelkipásztori munkát érintő kérdéseket, és gyakorlati következtetésekre jusson". Az Ad Gentes határozat 30 pontja azt emeli ki, hogy püspök a „nagyobb összhang érdekében lehetőleg állítson fel” lelkipásztori tanácsot, amelyben papok, szerzetesek és világiak küldöttként képviselik a krisztushívőket. $\mathrm{Az}$ Ad Gentes dokumentum kijelentéseit - Arrieta neves egyházjogász szerint nagyobb összefüggésben kell elemezni, hiszen azok elősorban az egyetemes egyház missziójáról szólnak. Az egyházmegyében pedig ezzel a missziós feladattal, valamint a missziós célok koordinálásával a püspök van megbízva nem pedig a pasztorális tanács, ahogyan arra hivatkozni szoktak (Arrieta, 1981).

Apostolicam Actuoritatem határozat bár közvetetten utal a pasztorális tanácsra, azt kéri, hogy a klerikusok, szerzetesek és a világiak „együttmüködésével” szervezzék meg minden egyházmegyében azokat a tanácsokat, amelyek segítik az egyház apostoli tevékenységét. A Presbyterorum Ordinis határozat 7. pontjához füzött magyarázat pedig világosan megkülönbözteti a pasztorális tanácsot a papi tanácstól, illetve a szenátustól, mely utóbbinak az a feladata, hogy tanácsaival a püspököt - a szükségletek 
szerint -, „az egyházmegye kormányzásában támogassa”. A lelkipásztori tanács „feladata csupán a lelkipásztori problémák szemmel tartása”. Ennek a megalakítása fakultatív jellegü.

A zsinat utáni dokumentumok (Erdő, 1982) közül az Ecclesiae Sanctae kezdetű motu proprio sürgeti leginkább a zsinat gondolatainak gyakorlati alkalmazááa (Paulus VI. 1966).

Az 1971-es püspöki szinódus „A szolgálati papság” című dokumentumában a pasztorális tanáccsal kapcsolatban kifejti a papok és a világiak kapcsolatát: „Minél inkább fokozódik napjainkban (mindenekelőtt a papi szenátusok révén) a püspökök és papok közös felelőssége (Gaudemet, 1973), annál kívánatosabb, hogy az egyes egyházmegyékben létrehozzák a pasztorális tanácsokat."

A Kléruskongregáció Omnes Christifideles 1973. január 25-én kiadott levelében is az áll, ha a megyéspüspök a püspökkari konferenciával és a saját presbitériumával folytatott közös megbeszélés után úgy dönt, hogy az adott feltételek megvannak, állítsa fel a pasztorális tanácsot, és alkossa meg annak szabályzatát. A körlevél azt is megfogalmazza, hogy „az egyházmegyében lévő tanácsoknak, legyen az plébániai vagy kerületi szintü, ugyanaz a természetük". Ez a körlevél az egyetlen olyan zsinat utáni dokumentum, amely kifejezetten foglalkozik a pasztorális tanáccsal, valamint ez az első, amely megemlíti a plébániai pasztorális tanácsot is.

1973. február 22-én a Püspöki Kongregáció által kiadott a püspökök lelkipásztori szolgálatáról szóló Ecclesiae Imago direktóriuma kifejti, hogy amennyiben a püspök a lelkipásztori munka érdekében hasznosnak ítéli, minden plébánián alakítsanak pasztorális tanácsot a már létező más apostoli munkát végző központok mellett, és ezeket az egyházmegyei pasztorális tanács koordinálja. A tanács egyházmegyei szintű koordináló szerepe itt már újdonságként szerepel. A koordinálás tekintetében nem az egyházmegye jogi struktúrájához tartozó tanácsadó szervezetről van szó - amint a papi szenátus esetében ez egyértelmü -, hanem inkább az egyház anyai gondoskodó szerepéről, amikor a különböző csoportok közötti harmóniát akarja szabályozni (v.ö. Arrieta, 1981). Ez a dokumentum hatályát vesztette a 2004-ben életbe lépett az Apostolorum Successores elnevezésű direktóriummal, és a korábban felmerült bizonytalanságokat gyakorlatilag tisztázta.

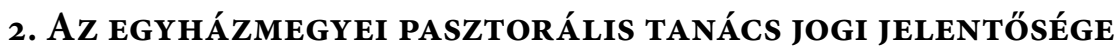 A HATÁlyos KóDEXBEN}

Az 511. kánon szerint a tanács létesítése kötelező, ha azt a lelkipásztori körülmények indokolják. A Kléruskongregáció 1973-as Omnes Christifideles körlevele arra hívja a püspököket, hogy az adott kérdést a püspöki konferencia elött, valamint az egyes püspökök saját presbitériumokkal megtárgyalva döntsenek afelől, hogy fennállnak-e ezek a lelkipásztori körülmények.

A tanács illetékességét tekintve a tanácsnak nem feladata a lelkipásztori 
tevékenységek megvalósítása (Denis, 1967). Mivel csak a lelkipásztori munkát „érinto"” kérdésekkel foglalkozhat, ebből kifolyólag hármas funkciója van: vizsgálni, mérlegelni és gyakorlati következtetéseket előterjeszteni.

A pasztorális tanácsnak nincs illetékessége bármit is kijelenteni, ami a hit és az ortodoxiát érintő általános kérdéseket, a morális elveket vagy az egyetemes egyház jogát érinti, hiszen az egyházmegyében a legfőbb tanító a püspök. A pasztorális tevékenységeknek a gyakorlatban pedig a papi szenátus a tanácsadó szerve. Természetesen azokban a kérdésekben, amelyek az egyházmegyében folyó missziós, kateketikai és apostoli munkát érintik, valamint amelyek a hívők szentségi és hitéletével kapcsolatosak, a pasztorális tanács előterjeszthet véleményt. Ezenkívül a tanács segítségére lehet a papoknak az egyházmegye különbözö társadalmi és szociális területeinek lelkipásztori ellátásában, valamint az egyház közéleti tevékenységében is. Tanácsadási jogköre csak az egyházmegye területére szól.

Az 512. kánon megfogalmazása szerint „a katolikus egyházzal teljes közösségben lévő krisztushívő"k lehetnek a tanács tagjai. Ez a kritérium nem jelenti azt, hogy a tanács elzárkózik az ökumenizmus gondolatától, hiszen a lelkipásztori munkát érintő kérdések nem elhanyagolandó részét - főleg napjainkban - éppen a más egyházakkal, egyházi közösségekkel (v.ö. Kránitz 2019) folytatott dialógus képezi. Ezt az egyetemes jog is elöírja a 383. kán. 3. \$-ban, amikor a megyéspüspök pásztori feladatait fogalmazza meg.

A tanács tagjainak első kategóriájába a klerikusok (207. kán. 1. §) tartoznak. A második csoportot a megszentelt élet intézményeinek (573. kán.) tagjai képezik de a hasonlóság miatt ide tartoznak még az apostoli élet társaságai is. A harmadik csoportot pedig „fóként” a világiak alkotják (Erdő, 1993).

A tagok kinevezése a püspök szabad döntésén alapul. Hasonlóan a papi szenátushoz a tagokat egyrészt választják, másrészt hivatalból nyerik el a tagságot, $s$ végül egyeseket a püspök szabadon nevez ki. Fontos kiemelni, bármilyen módon is történik a tagok kinevezése, nem beszélhetünk szoros értelemben kánoni választásról (vö. 164-179. kán.).

A krisztushívőket úgy kell kiválasztani, „hogy teljességében és valóban tükrözzék Isten népének az illető egyházmegyét alkotó részét” (512. kán. 2. \$).

A tanács tagjainak nincs képviseleti joguk, a saját nevükben, és személyes ismérveik alapján cselekszenek. Megkívánt tőlük, hogy teljes közösségben (v.ö. Erdő, 1996) legyenek a katolikus egyházzal (512. kán. 1. §), s tűnjenek ki „biztos hitükkel, jó erkölcsükkel és okosságukkal” (512. kán. 3. §).

A pasztorális tanács mint jogi intézmény a klasszikus értelemben nem állandó, hiszen egy bizonyos időtartamra létesítik (Coriden et al., 1985).

A kánon szerint a pasztorális tanácsot a püspök létesíti. A tanács által megalkotott szabályzat (91. kán. 1. §.) csak a megyéspüspök jóváhagyásával emelkedik jogeröre. A tanácsnak, mint jogi valóságnak a létesítését, valamint szabályzatának jóváhagyását a 474. kánon szerint írásban kell rögzíteni. Fontos itt megjegyezni, hogy a tanács 
tagjainak a hivatala pasztorális tanácsadói jellegü, éppen ezért nem képezik részét az egyházmegyei hivatalnak (469. kán.).

Mivel a pasztorális tanács a püspök tanácsadó testülete, ezért teljesen nyilvánvaló, hogy széküresedéskor a tanács megszűnik. Az újonnan kinevezett püspök saját belátása szerint, az 511. kánon figyelembevételével újra létesítheti a pasztorális tanácsot (Coriden et al., 1985).

Az 514. kánon az összehívás, az elnöklés, valamint a tárgyaltak közrebocsátásának jogát is a püspök illetékességének körébe sorolja. Ebböl következik, hogy minden olyan összehívás, amely a püspök beleegyezése nélkül történik, érvénytelen.

A pasztorális tanács tanácsadási joga teljesen fakultatív. A jog sehol sem írja elő, hogy a püspök valamilyen jogcselekmény megkezdése elött köteles kikérni vagy meghallgatni a tanács véleményét, természetesen ezt megteheti, de semmi esetre sem az érvényesség vagy a megengedettség terhe alatt (Witsch, 2004).

A kánon a tárgyaltak közrebocsátását egyedül a püspök jogának (unice spectat) tartja fenn, így a tanács tagjaira egyfajta kötelező titoktartást ró ki. Az ülésen elhangzott vélemények, viták, megegyezések, végső következtetések nem kerülhetnek nyilvánosságra, csak akkor, ha azokat a püspök közrebocsátja.

Végül a pasztorális tanács összehívását a Kódex úgy határozza meg, hogy évente legalább egyszer történjék meg.

\section{A plébániai pasztorális tanács teológiai Jelentősége a zSINATI ÉS AZ AZT KÖVETŐ MEGNYILATKOZÁSOKBAN}

A plébániai pasztorális tanács fogalma újdonság a Kódexben, bár alapjait nem a zsinati szóhasználatban találjuk, mégis sok szerző - ugyan tévesen - a zsinat szellemiségéből vezette le a tanács létrehozását.

A Kléruskongregáció Omnes Christifideles levele tette később lehetővé, hogy az egyházmegyei pasztorális tanács analógiájára hozzák létre a plébániai pasztorális tanácsot. A körlevél szerint „az egyházmegyében lévő tanácsoknak, legyen az plébániai vagy kerületi szintü, ugyanaz a természetük”.

A zsinat utáni dokumentumok nem hivatkoznak az AA 26 határozatra, mint a plébániai pasztorális tanácsa teológiai forrására. Ez a körlevél az egyetlen olyan zsinat utáni dokumentum, amely kifejezetten megemlíti a plébániai pasztorális tanácsot. Megállapítható tehát, hogy a zsinati dokumentumokra való hivatkozás csupán egy utólagos értelmezési mód.

A II. vatikáni zsinat eredeti szándékát a plébániai pasztorális tanácsot illetően, az AA dokumentum 26. pontjának előírása fedi fel: „minden egyházmegyében szervezzék meg a tanácsokat, melyek segítsék az egyház apostoli tevékenységét". Ennek plébániai szintű szerveződése a pasztorális tanács. Az apostoli jelző igen tág értelmü, hiszen beletartozhat az evangelizáció, a megszentelés, a karitatív és szociális tevékenység is. Ezek a tanácsok képesek arra is, hogy „összehangolják” a világiak 
társulatait és kezdeményezéseiket. Nyilvánvalóan előírásokat nem szabhatnak, hiszen ezek a társulatok megőrzik a sajátos jellegüket és „autonómiájukat” (Fischer, 1999).

Az AA 26 értelmezési problémájának lényege a harmonizálás (koordináció) volt, miszerint a tanácsok feladata, hogy „összehangolják” a világiak különféle társulatait és kezdeményezéseit (Griese, 1985). Ezt sokan úgy értelmezték, hogy a tanács illetékességében tartozik a plébániai szolgálatok irányítása is.

A Kléruskongregáció legújabb instrukciója a fenti problémát megoldani látszik, amikor úgy fogalmaz, hogy a „plébániai pasztorális tanács fö feladata tehát az, hogy a plébánián megfogalmazódó pasztorális és karitatív kezdeményezések kapcsán gyakorlati javaslatokat keressen és tanulmányozzon, összhangban az egyházmegyei tervekkel" (Kléruskongregáció, 2020).

A plébániai pasztorális tanács teológiai értelemben az egyház lényegi valóságának része, ami azt jelenti, hogy a tanácsnak elsősorban nem adminisztratív, hanem evangelizációs feladata van. Amint ezt Ferenc pápa is megfogalmazza: a „tanács célja elsősorban nem az egyházon belüli szervezési feladatok ellátása, hanem az a missziós eszmény, hogy mindenkihez eljussunk" (Ferenc, 2014).

\section{A plébániai pasztorális tanÁcs Jogi Jelentősége A HATÁlyos KóDEXBen}

A partikuláris jog specialitásaként van számontartva a magyarországi egyházközségi képviselő-testületek jogintézménye, amelyet Magyarországon a II. világháború után mindenütt bevezettek és legitim módon működött. Ez a testület nem a püspöktöl független szervezetként tevékenykedett, hanem a részegyház hierarchikus szervezetében törvényes helyet kapott. Az egyházközségi képviselötestületek intézményes tevékenysége megegyezik a II. vatikáni zsinat által később javasolt plébániai képviselő-testület feladataival és jogkörével.

Mivel az egyházközségek kezdetben nem rendelkeztek jogi személyiséggel, később azonban az állami törvények ezeket önálló jogi személyeknek elismerték, valamint az 1983-as Kódex kihirdetésével a törvényesen alapított plébániák, magánál a jognál fogva jogi személyiséggel rendelkeztek (515. kán. 3. §), ezért szükségesnek látszott a két jogi személy közötti kapcsolatot jogilag is tisztázni.

A Püspöki Konferencia által 1993. január 2-án kiadott „A Magyarországi Egyházközségi Képviselőtestületek Szabályzata” (MEKSz) bevezető rendelkezése a következőket állapítja meg: „Ezentúl az egyházközség szót, mint a plébánia közösségének szép régi magyar elnevezését használjuk."

A püspöki konferencia rendelkezése szerint a plébániai egyházközségi képviselötestület az a tanács, amely - az egyetemes jog ajánlása szerint - a plébániai pasztorális tanács feladatát betölti. Ezért a pasztorális tanácsra vonatkozó normák értelmezésekor hivatkozunk a MEKSz rendelkezéseire is. 
A plébániai pasztorális tanács alapítását a hatályos egyházjog a megyéspüspök illetékességre bízza, miután meghallgatta a papi szenátusát (536. kán. 1. §). Ezt rendes körülmények között, „nagyon ajánlatosnak kell tekinteni”, amint ezt Ferenc pápa is megerősíti: „Egy plébános sem vezetheti a plébániáját pasztorális tanács nélkül” (Kléruskongregáció, 2020).

A tanács egy olyan egyházi szervezet, amelyben az összes krisztushívő együttműködése és közös felelősségvállalása révén a plébániai közösség életét és növekedését szolgálja. Ennek alapvető rendeltetése, hogy „intézményes keretek között biztosítsa a hívők együttmüködését a sajátosan papi és lelkipásztori tevékenységben (Kléruskongregáció, 2003). Tanácsadási szerepével segíti a lelkipásztori tevékenység előmozdítását. A plébános figyelmesen meghallgatja a tanácsa által megfogalmazott véleményeket. A tanácsnak nincs döntési, vagy határozati joga, csupán tanácsadói természetű. A II. vatikáni zsinat egyházképe alapján, a tanács összetétele a plébániához tartozó azon krisztushívők közösségéből áll, akik tanácsaikkal, javaslataikkal, véleményeikkel, a plébánossal együttműködve szeretnék támogatni az evangelizáció, a liturgikus élet és a testvéri szeretet szolgálatát. A tanácsnak különösen is feladata, hogy a plébániai közösség pasztorális programját kidolgozza, amely összhangban van az egyházmegyei és egyetemes egyház pasztorális irányelveivel. Segíti a plébánost hivatalának ellátásában, a közösség részéről felmerült kérdéseket mérlegeli és ezek megoldására javaslatokat terjeszt a plébános elé. A plébániai csoportok és egyesületek közös együttmüködését segíti, valamint a rájuk vonatkozó döntések végrehajtását is támogatja, előmozdítja a missziós tudatot és tevékenységet.

A kléruskongregáció instrukciója a kódexre hivatkozva állítja, hogy a plébániai pasztorális tanács összetételét tekintve „olyan tanácsadó testület, amelyet a megyéspüspök által lefektetett szabályzat irányít, meghatározva összetételének kritériumait, a tagok megválasztásának módjait, a célkitűzéseket és a munkamódszereket" (Kléruskongregáció, 2020). A dokumentum figyelmeztet továbbá arra a törekvésre, hogy „a pasztorális tanács inkább olyan személyekből álljon, akik a plébánia lelkipásztori életében ténylegesen felelősséget viselnek, vagy akik ott konkrét feladatokat látnak el”.

A tanács összetétele hivatalból, valamint választott tagokból áll. Élén a plébános áll, tagjai közé tartozik még a plébános helyettes, valamint azok a papok és diakónusok, akik a plébánia lelkipásztori ellátásában részt vesznek. A különböző plébániai csoportok és intézmények (karitatív, liturgikus, kateketikai, gazdasági, katolikus iskola, média) vezetői pedig hivatalból tagjai a tanácsnak.

A pasztorális tanács speciális környezetet alkot, ahol a hívek azt a jogukat és egyben kötelességüket gyakorolhatják, hogy „kifejezzék a lelkipásztorok felé a saját gondolataikat a plébániai közösség javát illetően, s közöljék azokat a többi hívővel is" (Kléruskongregáció, 2020).

Az a krisztushívő lehet a tanács tagja, aki ismerten vallásos és tevékeny hívő, aki valódi feladatot lát el, példamutató egyéni és családi életet él, apostoli lelkületü, józan 
ítélőképességű és fegyelmezett tárgyalókészséggel rendelkezik. A plébániai közösségi életben tevékenyen részt vesz, egyházias lelkületével képes a pasztorális kérdések mérlegelésére.

A tagok megbízása általában öt évre szól, a főpásztor azonban meghatározhat rövidebb időt is.

A pasztorális tanács elnöke a plébános, vagy ha világi kisegítő lelkipásztorra van bízva a plébánia, akkor ez a személy a plébános mellett ügyvivő elnökként müködik. Magyarországon a képviselö-testület tagjai maguk közül választják meg a világi elnököt, aki az egyházi elnök (plébános) mellett és felügyelete alatt tevékenykedik.

A Kléruskongregáció instrukciója arra szólít fel, hogy „két szélsőséget kell elkerülni: egyrészt azt, hogy a plébános csak a kész döntéseket hozza a tanács tudomására, vagy csak ritkán és formálisan hívja össze a tanácsot; másrészt pedig azt, hogy a plébános a tanácsban csak egy tagként szerepel, gyakorlatilag megfosztva a közösségben betöltött pásztori és vezetői szerepétől” (Kléruskongregáció, 2020). Érvénytelenek tehát azok a döntések, amelyeket a plébános nélkül, vagy annak ellenére hoz a tanács.

A pasztorális tanács mint tanácsadó testület „,nem tanácsot ad” az illetékeseknek, hanem "tanácsot tart” azért, hogy az egyházmegyei és a plébániai közösség egyre hüségesebb legyen az evangéliumhoz, valamint a termékenyebb legyen a szeretetben (Borras, 1992). Ebből az aspektusból nézve nem a vélemények ütköztetése, a gondolatok kicserélése, a megyéspüspök vagy a plébános meggyözése a cél, hanem a szinodalitásnak az az útja, amelyben a közösen és felelösen gondolkodók a saját pásztor vezetése alatt - a különböző karizmáik kibontakoztatásával - megvalósítják az egyház misszióját. Az egyházmegyei valamint a plébánai pasztorális tanácsra vonatkozó elöírások megmutatják, „hogyan lehet alkalmazni a kánonjogi irányelveket, melyek meghatározzák a lehetőségeket és a korlátokat, a lelkipásztorok és a világi hívek jogait és kötelességeit. Céljuk, hogy a plébánia megtalálja önmagát mint az evangélium hirdetésének, az Eucharisztia ünneplésének, a testvéri és szeretet alkalmainak alapvető helyét, ahonnan az egész világra kisugárzik a keresztény tanúságtétel" (Kléruskongregáció, 2020).

Kapcsolattartó szerzö:

Liczenbold Levente

Egri Hittudományi Főiskola

3300 Eger

Foglár György u. 6, linlevente@gmail.com
Correspondending author: Levente Liczenbold Theological College of Eger Foglár György str. 6, 3300 Eger, Hungary linlevente@gmail.com 


\section{IRODALOMJEGYZÉK}

Arrieta, J. I. (1981). El régimen jurídico de los Consejos Presbiteral y Pastoral. Ius Canonicum, 21(42), 567-605.

Aymans, W., Mörsdorf, K. (1991). Kanonisches Recht I. Paderborn.

Borras, A. (1995). Petite grammaire canonique des nouveaux ministres. Nouvelle Revue Théologique, 117(2), 240-261.

Coriden, J. A., Green, Th. J., Heintschel, D. E. (1985). The Code of Canon Law. A text and commentary. New York-Mahwah.

Denis, J. (1967). L'Église diocésaine et la lumière de Vatican II, le Conseil du presbyterium et le Conseil diocésain de pastorale. Studia Canonica, 1(1), 185-193.

Erdő, P. (1982). Tanácsok, bizottságok és más pasztorális szervek a zsinat utáni egyházjogban. Teológia, 16(4), 244-246.

Erdő, P. (1993). A világiak munkája a plébánián. Távlatok, 3(12-13), 632-635.

Erdö, P. (1996). Az Egyházjog Teológiája intézménytörténeti megközelitésben. Budapest.

Ferenc Pápa. (2014). Evangelii Gaudium. SZIT.

Fischer, M. (1999). What Was Vatican II's Intent Regarding Parish Councils?. Studia canonica, 33(1), 5-25.

Gaudemet, J. (1973). Sur la co-responsabilité. L’Année Canonique, 17(1), 533-541.

Griese, O. (1985). The New Code of Canon Law and Parish Councils. Homiletic and Pastoral Review, 85(4), 47-53.

Kléruskongregáció. (2003). A pap mint a plébániai közösség pásztora és vezetője. Római Dokumentumok XXIII.

Kléruskongregáció. (2020). A plébániai közösségek lelkipásztori konverziója az egyház evangelizáló küldetésének szolgálatában. Római dokumentumok LIV.

Kránitz, M. (2019). Keresztény egység. Budapest.

Magyar Katolikus Püspöki Konferencia. (1993). A Magyarországi Egyházközségi Képviselö Testületek Szabályzata. DM Nyomda.

Paulus VI. Motu Proprio Ecclesiae Sanctae. (1966). In L. Erminio (Ed.), Enchiridion Vaticanum. (696-769). Edizione Dehoniane.

Renken, J. (1993). Pastoral Councils: Pastoral Planning and Dialogue among the People of God. The Jurist, 53(1), 132-154.

Sacra Congregatio Pro Episcopis. (2004). Directorium Apostolorum Successores. Libreria Editrice Vaticana.

Witsch, N. (2004). Synodalitat auf Ebene der Diözese. Die Bestimmungen des universalkirchlichen Rechts der Lateinischen Kriche. Padenborg. 